\title{
As Others See Us: Canada's Exports to the U.S.A.
}

\section{Introduction}

On August 22-23, I attended the Blaine House Conference on Maine/ Canadian Trade in Augusta. This is an annual event. The purpose of the Conference was never really explained other than in the broadest term, i.e. "Maine/Canadian Trade".

I do not intend to render a blow-by-blow account of the proceedings, and what follows are my perceptions which of course could be wrong. Here follows copy of the Governors' opening remarks plus "highlights" of three trade patterns between Maine and eastern Canada: forest products, agricultural products, fisheries products.

The atmosphere was most certainly friendly and cordial; however, in spite of the recognition of the fact that the dollar exchange rate is the principal culprit, in spite of the fact that our stumpage has been shown to not constitute a subsidy. . in spite of the various facts, the discussion always reverted to the U.S. unemployment said to be caused by "low-priced" Canadian imports, be these imports lumber, swine, porc, potatoes, shoes, etc., etc. In other words, facts seem to not be relevant.

So, what to do? I don't think that we as lumber people, as pulp people, as paper people, as potato people, as pork people, as fish people, can really do much that will stand a chance of reversing the very obvious unprotectionist sentiment now rife. The goal posts will keep on being moved until the playing field is of such a nature as to guarantee a victory. I think we should all be urging our federal government to commence negotiations immediately, with Washington on a very broad trade treaty, the details of which I shall not get into now. I do not see any other viable alternative, although there well may be one.

Events in the U.S./Canada trade field change daily. President Reagan has just indicated the resolve of the US Administration to resist protectionist actions and to work hard to obtain freer trade. By the time this item is published things may have changed for the better of for the worse. It is a terriby serious matter and one that must obtain the total effort of the Canadian Government. ।

D.D. Lockhart, APF

Executive Director

NB Forest Products Association Inc.

\section{Remarks of \\ Governor Joseph E. Brennan \\ Blaine House Conference on Maine/Canadian Trade}

Trade between Canada and Maine was not always a dignified subject, suitable for discussion at learned conferences like this one. Around the turn of the century, the political satirist William Pattangall - who incidentally went on to become state legislators Attorney General and Chief Justice of the Maine Supreme Court - visited the border city of Calais. He claimed they had a statue of Henry Clay in the public square with this inscription: "The Father of Protection, the Man Who Made Smuggling Possible, the Patron Saint of Calais".

He went on to describe the occupations of the Calais residents: "There are large families here living on the interest of the duties they didn't pay. Most of the rest of the population are employed in the Custom House. At present a few are in jail, and the remaining nineteen are Democrats".

Of course, these generalizations are no longer true today. It is now considered respectable to be involved in international trade. It's even considered respectable to be a Democrat!

But seriously, I cannot think of a more critical issue than the one you will be discussing the next two days. A few weeks ago, it was one of the most prominent issues discussed by the nation's governors at our summer meeting in Idaho. It is little wonder. This year the United States' trade deficit is approaching $\$ 150$ billion. The deficit with Canada is over $\$ 20$ billion, second only to Japan's $\$ 33$ billion. All summer long the newspapers have been filled with stories about the problems facing Maine farmers, fishermen, and lumber mill operators, due to the loss of markets to Canadian imports. Because of these problems, the subject of Maine/Canadian trade has become a most sensitive, and highly charged issue.

As we proceed to discuss it, it is important to remember those things that bring the people of Maine and the people of Canada together. For we share more than a common border. When I visit Quebec and the Maritime Provinces, I do not feel $\mathrm{I} \mathrm{m}$ in a foreign country. I feel I'm in a neighbor's home - a good neighbor. In fact, we are, in a real sense, more than neighbors. We are family. As many as one third of the people who live in Maine can trace part of their ancestry to either Quebec or the Maritime Provinces. We share time-honored business and cultural exchanges. Above all, we share in the cooperative spirit of people who have been good friends and good neighbors for many generations. And that history is the basis of our hope for the future. It is also the basis of our ability to listen, and help each other, today.

To understand each other, we must first agree on what is happening. There is currently great dispute about how much the federal and provincial governments of Canada subsidize their industries, and about what effect these subsidies have on trade and competition. But there are certain facts that cannot be disputed, such as the folliwing:

The Canadian portion of the United States softwood lumber market has grown from $19 \%$ a decade ago, to over $30 \%$ this year.

This year over half of the softwood lumber sold in the State of Maine will have been processed in Canada.

The Canadian portion of the New England fresh groundfish market doubled from $6 \%$ to $12 \%$ between 1979 and 1983.

In 1979-80, just under 1000 truckloads of Canadian tablestock potatoes passed over the Maine border. This year, over 5000 trucks of Canadian potatoes came through our state - a fivefold increase.

A major cause of the rising tide of Canadian imports has been the dramatic shift in exchange rates. Ten years ago, the American dollar and Canadian dollar were almost equal in value. Today, one Canadian dollar is worth roughly $70 \mathrm{c}$ in American currency.

Finally, because these less expensive imports are coming into slow-growing markets - and in the case of lumber, a market that has actually declined in the last five years - their effect has been to depress prices. The retail prices of fish and potatoes have declined in constant dollars over the last five years. And the wholesale price of lumber in constant dollars has declined as well.

Among all the states, Maine has a special problem with Canadian imports. No other state in the nation relies so heavily on the combination of fish, potatoes, and lumber, that Maine does. And no other state in the nation faces such 
direct and intense competition from a country on its immediate border.

The problem is compounded, because Maine and the eastern Canadian provinces are selling the same things, to the same people, in slow growing markets. The gains of Canadian industry in the last five years have been made largely at the expense of Maine jobs and Maine income. As a result, at lumber mills in the northern woods, on family farms in the St. John Valley, on fishing boats in the Gulf of Maine: jobs are disappearing, income is drying up. and Maine families are hurting. Because of this special situation, we have called this Blaine House conference. Our aims in meeting this week are threefold. Our first aim is simply to get out the facts on Maine/ Canadian trade: for the benefit of our own Maine businesses; for the benefit of our federal government; and for the benefit of our Canadian friends.

Our second aim is to find ways to help those American families who are losing jobs or, indeed, facing bankruptcy, because of Canadian competition. This is a challenge - and I want to emphasize this - for Canadians as well as the Mainers. For if we cannot help these Maine families; if we cannot restore their jobs; if we cannot maintain their way of life; then the inevitable result will be walls of protection. In fact there are already bills in the United States Congress to limit imports of Canadian lumber, and petitions before the ITC to impose duties on Canadian fish. If these proposals are enacted, the results could be disastrous for the economy of the eastern provinces. We must work together, to find better answers than protectionism.

The third aim of this conference is to identify long term economic prospects that would benefit both eastern Canada and Maine, such as: diversifying the region's agricultural base, and expanding markets for fish and lumber products.

There are no easy answers to these issues. But the answers we do come up with, I can guarantee you, will be reviewed carefully in the capitals of every New England state and every eastern Canadian province, as well as in Ottawa and in Washington.

In order to begin the process let me suggest some directions for your consideration in the next two days. I'll start with the long-term challenge.

Twenty five years ago it was possible for Maine businessmen to make decisions about lumber, fish, or farm investments without paying serious attention to what was going on to the north and east in Canada. Those days are gone forever. The growth of Canadian industry; and the improved communications, transportation and marketing networks that now exist; mean that the future prospects for Maine's natural resource industries will always be linked to their Canadian counterparts. Today we hear of problems in the fisheries, or in agriculture or in lumber, only after harm has been done. The Governors and Premiers, and the federal governments of Canada and the United States, need a long-term planning capability to help iden- tify and address such issues before they become serious problems. And on the positive side, they need a similar capability to identify and exploit opportunities for mutual economic development: in tourism, in energy, and in marketing.

To accomplish both of these, I recommend that trade policies become a major part of the regular agenda of the Eastern Canadian Premiers and New England Governors Annual Conference. Prior to the annual meeting, staff from the Annual Conference, should prepare papers identifying the problems in our trade relationship and the potential solutions. The underlying principle behind this proposal is that no long-run progress will be made on issues relating to Canadian/American trade without serious, on-going planning, and thoughtful discussion.

The short-term challenge the conference faces is more difficult to address. The options are fewer, the time is shorter, the possibilities for agreement more limited. As I already mentioned, there is a very active campaign underway to increase duties and limit Canadian imports. This will doubtless be resisted, and resented by our neighbors to the north. But, in the face of an historically unprecedented trade imbalance, and in the face of the loss of jobs and the disruption of Maine communities, some kind of action is inevitable.

Trade restrictions are a last resort. They make future cooperation more difficult, and must be avoided whenever possible. But to avoid them, we cannot go on pretending that problems do not exist. Both we in Maine, and our neighbors in Canada, must take steps to alleviate the most serious irritants in our trade relations. This means: better enforcement of potato quality standards, so that low quality potatoes - damaging to both Maine's and Canada's competitiveness with western brands - are not passed through to consumers. It means a more regular flow of fish and better information about scheduled fish shipments, so that large quantities of Canadian fish do not suddenly arrive and depress prices for everyone. And it means better enforcement of weight limits for trucks carrying logs and lumber, so that our highways are not damaged, and our lumber prices reflect real transportation costs.

In the longer-term, we have to find ways to expand markets for our products, rather than constantly fighting over limited shares of slow-growing markets. Take the example of fish. The average Canadian or American eats between 10 and 15 pounds of fish per year. The average Norwegian eats over twice as much fish. The average Japanese eats about four times as much fish. We should be fighting together to increase fish consumption and market shares for both countries, rather than fighting with each other over how much of the existing small market we can control Likewise, we need to expand markets for our lumber and seed potatoes by increasing our exports overseas. We can work together in all these areas, just as we are already working jointly to market the wild blueberries and the lamb grown in Maine and the Atlantic Provinces

These are the things that the State of Maine, the provinces of Canada, and the private sector, can do togehter. But even if we begin to do all of this tomorrow, it still won't be enough to help those Maine families who are suffering today. The power to help these people does not lie in our state capitals or provincial capitals. It lies in Washington and Ottawa. I am talking now about the actual power to influence the international monetary markets, and the exchange rate of the dollar. I am talking now about the actual power to negotiate mutually beneficial trade agreements.

To date, in the face of the American trade deficit which is totally out of control, much that comes out of our nation's capital is hollow platitudes about free trade. The President needs to see what is happening in Maine, and throughout this country, as a result of this nation's bankrupt trade policies; and he needs to move strongly and decisively to correct the situation, and to enable our industries to compete effectively once again.

As I said earlier, there are no easy answers to our problems. What answers there are require understanding and cooperation from the parties: Maine businesses and Canadian businesses; provincial governments and state governments; Ottawa and Washington.

AS YOU DEBATE THESE ISSUES THE NEXT TWO DAYS' I urge you to keep in mind the long and proud association of the Eastern Canadian provinces and the State of Maine. Keep in mind our deep and enduring friendship that goes far beyond our present trade problems.

We are more than friends. We are family. And as family, we must work together.

\section{Forest Product Trade Patterns Between Maine and Eastern Canada}

*Maine has over 17 million acres of timber. It is $89 \%$ forested, making it the most heavily forested State in the country. There are over 30 forest types in the state, but spruce-fir dominates nearly half the forest area. $96 \%$ of the forest is privatelyowned. Forest industry owns $47 \%$ or 8 million acres. Maine has the highest proportion of industrial ownership of any state in the union.

*The State of Maine has more border in common with Quebec and New Brunswick than it does with the rest of the United States. Cultural and historical ties between Maine and eastern Canada are deeply-rooted. This intimate relationship is very obvious in how the wood industries on both sides of the border depend upon and relate to one another. The Canadian influence on Maine's industry and landowners is much more complex than other forested states.

*Much of Maine's commercial timberland in northern and western Maine is closer to Canadian labor and sawmills than to cit- 
ies and towns in Maine. Approximately 900 bonded Canadian laborers were needed by Maine woods contractors to harvest wood in these remote areas last year. American labor was not available.

* Much of the spruce-fir resource in this same area of Maine was victim of a spruce budworm epidemic over the last 10 years. 12-15 million cords of sprucefir, over some 3 million acres were lost to the budworm and only 5 million of that total is still salvageable. Landowners in northern Maine would be hard-pressed to salvage even a portion of that volume without the Canadian market and its lucrative price for sawlogs.

*Maine exports about 325 million feet of sawlogs to Canada each year, or roughly $1 / 3$ of the State's total sawlog harvest. Nearly 260 million feet, or $88 \%$, is sprucefir for dimension lumber. Half of the hardwood sawlogs exported from Maine to Canada, about 13 million board feet, are high grade rock maple.

Our best estimates show that Maine produces about $78 \%$ of the total volume of sawlogs from the NE region (including Vermont, Massachusetts, New Hampshire, and New York) that crosses the boundary into Canada.

In turn, Canada ships back $89 \%$ of the softwood lumber used in Maine annually. About $\$ 19$ million dollars of raw material (chips, sawlogs, pulpwood and poles) were imported into Maine in 1984 according to U.S. customs.

"Maine has about 300 sawmills throughout the State. Canadian mills have at least $25-30 \%$ operating cost advantage over most of these Maine sawmills at the moment, the exchange rate being a major factor. Two have closed during the past year because of causes including competition from Canadian lumber. Many more are "on the fence" and close to shutting down.

\section{Agricultural Trade Patterns Between Maine and Eastern Canada}

*The agricultural sector provides one of the most noted examples of trade problems between Maine and Canada and one of the most outstanding examples of cooperation. In recent years, Maine's potato industry has suffered from a steadily increasing flow of low-priced Canadian potato imports. Meanwhile, wild blueberry growers in Maine and Canada's eastern provinces have worked together to develop a successful cooperative promotion effort, coordinated by their joint organization, the Wild Blueberry Association of North America.

*Potatoes are Maine's number one agricultural crop. Annual cash farm receipts from Maine potatoes average more than $\$ 100$ million. Including the value added by potato processing, the state's potato industry generates about $\$ 400$ million in economic activity each year. Maine produces about 22 million hundredweight (cwt) of potatoes annually, and ranks as the third largest potato producing state.
*There are currently about 800 potato growers statewide, the majority of whom are located in Maine's northernmost county, Aroostook. Most Maine growers produce potatoes for the fresh tablestock market, though about $17 \%$ of the crop is sold to processors who market frozen potato products and potato chips.

*In recent years, Maine's potato industry has suffered from low prices caused by abundant potato supplies in the U.S. and a steady increase in low-priced Canadian imports. Canadian imports pose a particular problem for Maine because most are shipped into the same eastern markets upon which Maine's tablestock growers depend. The volume of Canadian potato imports has increased by about $500 \%$ during the past decade and are now at a level equal to roughly a quarter of Maine's entire crop. The substantially lower value of the Canadian dollar, compared with US currency, appears to be a major reason for the low prices of Canada's potato imports. Some observers, including the International Trade Commission, suggest that quality differences are the major reason for increased Canadian imports. However, recent quality inspection by the U.S.D.A. indicate that a least $2-\%$ of the potatoes from Canada do not meet minimum quality standards for imports.

\section{Fisheries Trade Patterns}

*Estimates of the equivalent full time jobs provided by Maine fisheries vary from 8 to 12 thousand, i.e. to 1 to $2 \%$ of the total number of state jobs. However, in Washington and Hancock counties the jobs provided by fishery and fish processing processing accounts for more than $25 \%$ of the total.

*Maine's annual catch during the first half of the ' 80 's (' 80 -' 84 ) has averaged 228 million pounds with a landed value (price to fishermen) of 102 million dollars. Maine leads all states in the production of lobster, soft clams, herring, ocean perch and marine bait worms.

*Maine's annual lobster catch has averaged 20.2 million pounds between 1974 and 1983. During this period the lobster fishery has provided almost half $(47 \%)$ of the fisheries landed value for the state.

Canadian lobsters shipped into the U.S.

$1978-12659000$

$1983-26500000$

$1984-30791000$

1985 - thru June - $20168000^{*}$

1984 - thru June - 17750000 *

* $14 \%$ increase

$95 \%$ of lobsters shipped into the U.S. enter through Maine ports of entry. This amounts to approximately 20 million pounds annually. In 1984 , about $10 \%$ of the Canadian lobsters shipped into Maine were destined for Maine Dealers.

*Ten years ago, Maine fishermen harvested about 25 million pounds of redfish in Canadian waters; however, since the
200 -mile limit went into effect, this fishery has declined substantially.

*Herring are both imported from Canada and exported to Canada. In 1978 Canada shipped 23547 metric tons of herring into Maine while Maine shipped 1804 metric tons to Canada. In 1981, Maine shipped about 12000 metric tons to Canada while Canada shipped 5000 metric tons to Maine.

*Northeastern US imports of the groundfish products of concern in this study increased from 252 million pounds, valued at \$294 million, in 1979 to 306 million pounds, valued at $\$ 372$ million, in 1983. Imports of fresh, whole groundfish increased more than twofold in quantity and threefold in value during 1979-83, and imports of fresh groundfish fillets increased by $73 \%$ in quantity and by $85 \%$ in value. Imports of frozen, whole groundfish decreased during the period but imports of frozen groundfish fillets increased $9 \%$ in quantity and $22 \%$ in value.

Northeastern U.S. imports of scollops ranged from 19 million pounds in 1979 to 25 million pounds in 1983. Such imports fluctuated during 1979-83 as available supplies in foreign countries, particularly Canada, were sporadic.

*Canada, by far, was the principal supplier of northeastern U.S. imports of groundfish and scallops during 1979-83, accounting for $58 \%$ of the total quantity and $57 \%$ of the total value. In the fresh market, Canada provided $99 \%$ of the quantity of northeast U.S. imports of fresh, whole groundfish and $96 \%$ of the quantity of fresh groundfish fillets during 1979-83. 


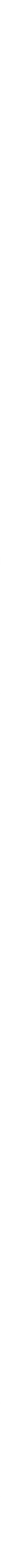

\section{INTRODUCING THE NEW BAUSCH \& LOMB RMS'" QUAD SYSTEM.}

\section{A TRULY PERSONAL SYSTEM}

Today's most affordable and practical stand-alone Resource Measurement System can now be used for digitizing USGS Quadrangle size maps. It's compact, fast, and easy to use for measurement, storage, retrieval, analysis, and plotting-right at your own desk.

\section{ELIMINATE MOSAIC PROCEDURES}

Thanks to the addition of a larger digitizing tablet with a 19-inch x 26-inch active area and complementary plotter, information can be quantified from the entire map. These technological advances make time-consuming mosaic procedures obsolete. A totally practical system, the RMS Quad provides resource managers and environmental specialists with the data needed-instantly, accurately, legibly.

\section{GET THE FACTS IN ANY FORM}

With a comprehensive menu to work from, it's user friendly, simple to operate. Even graphics, charts and graphs in hard copy form are yours at the touch of a key.

\section{GET MORE FOR YOUR MONEY}

Cost effective to own and operate, the new RMS Quad system is priced much lower than other comparable systems. You get the capability you demand without gimmicks you don't want or require.

It's the right instrument at the right price for your needs.

\section{GET MORE INFORMATION NOW}

Let us show you how much it can do for you. For detailed information, call (716) 338-6466, or write Bausch \& Lomb, Department 6694, P.O. Box 450, Rochester, New York, $14692-9961$.

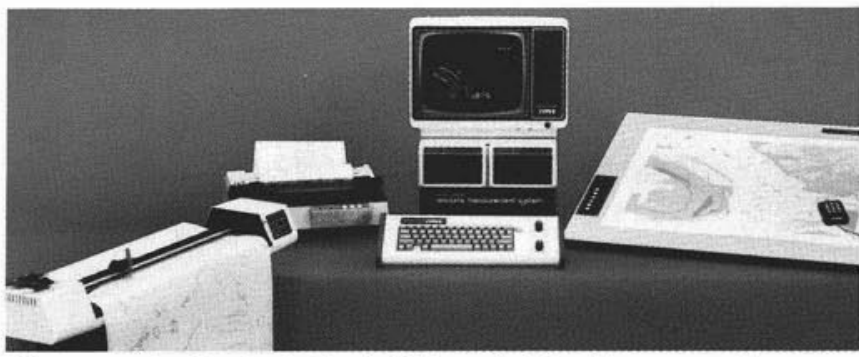

The recognized leader in the field, Bausch \& Lomb presents the new RMS $^{\text {TM }}$ Quad system for fast, accurate measurement and analysis at a modest investment.

\section{BAUSCH \& LOMB $\bigcirc$ \\ Optical Systems Division}

Bausch \& Lomb is a registered trademark

RMS $^{\text {TM }}$ is a trademark of Bausch \& Lomb Incorporated 